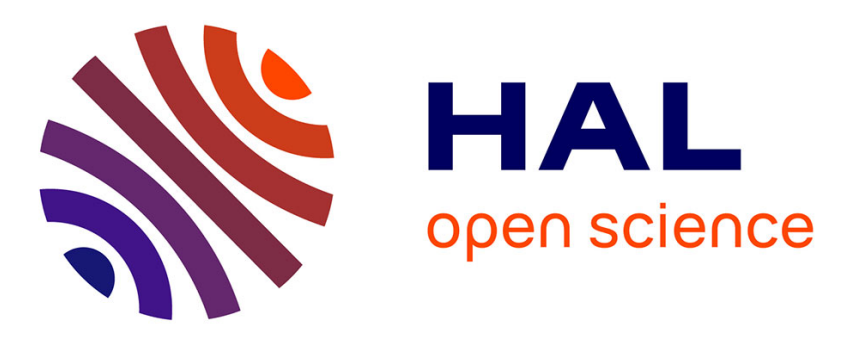

\title{
Sr1-xBaxSnO3 system applied in the photocatalytic discoloration of an azo-dye
}

Herbet Bezerra Sales, Valérie Bouquet, Stéphanie Députier, Sophie Ollivier, Francis Gouttefangeas, Maryline Guilloux-Viry, Vincent Dorcet, Ingrid Tavora Weber, Antonio Gouveia de Souza, Iêda Maria Garcia dos Santos

\section{- To cite this version:}

Herbet Bezerra Sales, Valérie Bouquet, Stéphanie Députier, Sophie Ollivier, Francis Gouttefangeas, et al.. Sr1-xBaxSnO3 system applied in the photocatalytic discoloration of an azo-dye. Solid State Sciences, 2014, 28, pp.67-73. 10.1016/j.solidstatesciences.2013.12.007 . hal-00990406

\section{HAL Id: hal-00990406 https://hal-univ-rennes1.archives-ouvertes.fr/hal-00990406}

Submitted on 13 May 2014

HAL is a multi-disciplinary open access archive for the deposit and dissemination of scientific research documents, whether they are published or not. The documents may come from teaching and research institutions in France or abroad, or from public or private research centers.
L'archive ouverte pluridisciplinaire HAL, est destinée au dépôt et à la diffusion de documents scientifiques de niveau recherche, publiés ou non, émanant des établissements d'enseignement et de recherche français ou étrangers, des laboratoires publics ou privés. 


\section{$\mathrm{Sr}_{1-\mathrm{x}} \mathrm{Ba}_{\mathrm{x}} \mathrm{SnO}_{3}$ system applied in the photocatalytic discoloration of an azo-dye}

Herbet Bezerra Sales ${ }^{a}$, Valérie Bouquet ${ }^{b}$, Stéphanie Députier ${ }^{b}$, Sophie Ollivier ${ }^{b}$, Francis Gouttefangeas ${ }^{1}$, Maryline Guilloux-Viry ${ }^{\mathrm{b}}$, Vincent Dorcet ${ }^{\mathrm{b}}$, Ingrid Távora Weber ${ }^{\mathrm{c}}$, Antônio Gouveia de Souza $^{a}$, lêda Maria Garcia dos Santos ${ }^{a,{ }^{*}}$

a'LACOM / INCTM, Universidade Federal da Paraíba, Campus I, João Pessoa, PB, Brazil ${ }^{b}$ Institut des Sciences Chimiques de Rennes, UMR CNRS 6226, Université de Rennes 1, Rennes, France

`LIMA, Instituto de Química, Universidade de Brasília, Brasília, DF, Brazil.

* Corresponding author: Prof. lêda Maria Garcia dos Santos

Phone/fax: (+55) 83 3216-7441

Mobile phone: (+55) 83 9967-5781

E-mail address: ieda@quimica.ufpb.br 


\section{ABSTRACT}

Semiconductor materials have received substantial attention as photocatalysts for controlling water pollution. Among these materials, perovskite-structured $\mathrm{SrSnO}_{3}$ is a promising candidate for this application, whereas $\mathrm{BaSnO}_{3}$ exhibits very low activity. In the present work, $\mathrm{Sr}_{1-\mathrm{x}} \mathrm{Ba}_{\mathrm{x}} \mathrm{SnO}_{3}(\mathrm{x}=0,0.25,0.50,0.75$ and 1$)$ was synthesized by solid-state reaction and was applied in the photocatalytic discoloration of the organic dye Remazol Golden Yellow. The perovskite structure was obtained for all compositions of the solid solutions with both $\mathrm{Sr}^{2+}$ and $\mathrm{Ba}^{2+}$ present in the lattice. A remarkable change in the shortrange symmetry was observed as the amount of $\mathrm{Ba}^{2+}$ increased, and this change led to a decrease in the band gap of the material. Although the $\mathrm{BaSnO}_{3}$ was not active toward water photolysis, the discoloration induced by this perovskite was twice that induced by $\mathrm{SrSnO}_{3}$. The two materials appear to feature different mechanisms of photodegradation: the direct mechanism prevails in the case of $\mathrm{BaSnO}_{3}$, whereas the indirect mechanism appears to play a key role in the case of $\mathrm{SrSnO}_{3}$.

Keywords: $\mathrm{BaSnO}_{3} ; \mathrm{SrSnO}_{3}$; perovskite; photocatalysis; adsorption; remazol yellow gold. 


\section{Introduction}

Stannates such as $\mathrm{CaSnO}_{3}, \mathrm{SrSnO}_{3}$ and $\mathrm{BaSnO}_{3}$ have been reported in the literature as compounds with the classic perovskite structure, with stoichiometry $\mathrm{ABO}_{3}[1,2]$. With respect to other perovskites, their Bravais lattice depends on the A cation. In this sense, $\mathrm{BaSnO}_{3}$ has an ideal cubic structure $[3,4]$ with space group $\mathrm{Pm} 3 \mathrm{~m}$ and is an n-type semiconductor with a band gap of approximately $3.4 \mathrm{eV}$, which is similar to the band gap of other photocatalysts such as $\mathrm{TiO}_{2}, \mathrm{SrTiO}_{3}, \mathrm{ZnO}$ and $\mathrm{ZnS}$ [5-7]. $\mathrm{CaSnO}_{3}$ and $\mathrm{SrSnO}_{3}$ have unit cells that differ from those of other perovskite-structured oxides; their unit cells are composed of distorted cubes and are classified as orthorhombic (space group Pbnm) because of the tilting of octahedra, and their band gaps are $4.4 \mathrm{eV}$ and $4.1 \mathrm{eV}$, respectively $[2,8,9]$. In these compounds, the local octahedral environment around $\mathrm{Sn}^{4+}$ is maintained and the corner-sharing octahedral connectivity of the perovskite structure is also preserved [2]. However, the difference in the symmetries are driven by a mismatch in the fit of the alkaline-earth cation to the cubic-octahedral cavity in the corner-sharing octahedral network; this mismatch is due to the smaller ionic radius of $\mathrm{Sr}^{2+}$ or $\mathrm{Ca}^{2+}$ compared to that of $\mathrm{Ba}^{2+}[8,9]$. As a consequence, a change in the Bravais lattice occurs when the A cation is changed.

These stannates exhibit interesting properties that lead to their application as stable thermal capacitors, high-quality humidity sensors and photoluminescent and photocatalytic materials [10-13]. The use of these materials for photocatalytic water splitting is well known $[14,15]$. Nonetheless, the literature contains very few studies on the use of perovskitestructured stannates for the photodegradation of organic dyes, although $\mathrm{SrSnO}_{3}$ has been 
synthesized by cyclic microwave radiation and used in the photocatalytic decolorization of methylene blue with high efficiency [16].

The objective of the present work was to obtain photocatalysts based on $\mathrm{Sr}_{1}$ ${ }_{x} \mathrm{Ba}_{\mathrm{x}} \mathrm{SnO}_{3}(\mathrm{x}=0,0.25,0.50,0.75$ and 1$)$ powders prepared by solid-state reaction and to evaluate the influence of the barium content on the structural characteristics of the materials as well as its influence on the ability of the photocatalysts to degrade a textile dye.

\section{Experimental procedure}

\subsection{Synthesis and characterization of the photocatalysts}

$\mathrm{Sr}_{1-\mathrm{x}} \mathrm{Ba}_{\mathrm{x}} \mathrm{SnO}_{3}(\mathrm{x}=0,0.25,0.50,0.75$ and 1$)$ powders were prepared by solid-state reaction $[8,17]$ using stoichiometric amounts of $\mathrm{BaCO}_{3}$ (JOHNSON MATTHEY S.A.; 99.99\%), $\mathrm{SrCO}_{3}(\mathrm{MERCK} ; 99.99 \%)$ and $\mathrm{SnO}_{2}(\mathrm{ALDRICH} ; 99.99 \%)$. The precursors were milled in a planetary mill using an agate vessel with a rotation speed of $400 \mathrm{rpm}$ for $26 \mathrm{~min}$. After being milled, the samples were calcined at $100{ }^{\circ} \mathrm{C}$ for $6 \mathrm{~h}$ with a heating rate of 5 ${ }^{\circ} \mathrm{C} \cdot \mathrm{min}^{-1}$. Powders were deagglomerated and calcined again at the following temperatures for crystallization of the perovskites: $1100{ }^{\circ} \mathrm{C}$ for $8 \mathrm{~h}$ for $\mathrm{SrSnO}_{3} ; 1250{ }^{\circ} \mathrm{C}$ for $6 \mathrm{~h}$ for $\mathrm{Sr}_{0.75} \mathrm{Ba}_{0.25} \mathrm{SnO}_{3}, \mathrm{Sr}_{0.50} \mathrm{Ba}_{0.50} \mathrm{SnO}_{3}$ and $\mathrm{Sr}_{0.25} \mathrm{Ba}_{0.75} \mathrm{SnO}_{3}$; and $1350{ }^{\circ} \mathrm{C}$ for $6 \mathrm{~h}$ for $\mathrm{BaSnO}_{3}$. All temperatures were optimized on the basis of the formation of the desired phases.

All of the powders were structurally characterized by X-ray diffraction with a twocircle Bruker D8 diffractometer using monochromatized Cu $\mathrm{K}_{\alpha 1}$ radiation $(\lambda=1.5406 \AA \hat{)})$. Data for Rietveld refinement of all of the samples were collected in the $2 \theta$ range of $10^{\circ}$ to $120^{\circ}$ at room temperature, and calculations were performed using the FullProf program [18]. 
Infrared spectroscopy measurements were performed in a Shimadzu IRPrestige-21 spectrophotometer over the wavenumber range of 2000 to $400 \mathrm{~cm}^{-1}$ using $\mathrm{KBr}$ pellets. Raman spectroscopy measurements were performed with an S/Witec Alpha 300 scanning near-field optical microscopy system equipped with a Nd:YAG laser source with a wavelength of $514 \mathrm{~nm}$ and an incident power of $150 \mathrm{~W} / \mathrm{mm}^{2}$. The data acquisition time was $125 \mathrm{~s}$ in a range between 0 and $2000 \mathrm{~cm}^{-1}$. The optical absorbance was measured by diffuse reflectance spectroscopy in a SHIMADZU model UV-2550 spectrophotometer in the wavelength region 190-900 nm, and the optical band gap values $\left(E_{g}\right)$ were determined using the method of Wood and Tauc [19]. The morphology was evaluated by field-emission scanning electron microscopy (FE-SEM, Joel 6301-F), which was operated at a low voltage $(7 \mathrm{kV})$ to limit charging effects and to achieve high resolution without the need for surface metallization. Microanalysis by energy-dispersive spectroscopy was performed with a JEOL model JSM 6400 (Oxford INCA).

\subsection{Photocatalysis and adsorption tests}

The $\mathrm{Sr}_{1-\mathrm{x}} \mathrm{Ba}_{\mathrm{x}} \mathrm{SnO}_{3}$ system was evaluated via the photo-oxidation of an organic textile dye, Remazol golden yellow (RNL), which is widely used in the textile industry. During the photocatalytic tests, $10.0 \mathrm{mg}$ of the $\mathrm{Sr}_{1-x} \mathrm{Ba}_{x} \mathrm{SnO}_{3}$ powders was added to a Petri dish containing $15.0 \mathrm{~mL}$ of a $10 \mathrm{ppm}$ aqueous solution of RNL with no stirring. All of the analyses were performed in triplicate at $\mathrm{pH}=6.0$. Experiments were conducted in a $10 \times 10$ $\times 100 \mathrm{~cm}^{3}$ lab-made reactor for $5 \mathrm{~h}$ using a UVC lamp $(\lambda=254 \mathrm{~nm})$ [20]. One test was performed under the same conditions without a photocatalyst for the measurement of the photolysis. 
An adsorption test without UV irradiation was also performed. The same amounts of powders $(10.0 \mathrm{mg})$ were added to an aqueous solution of RNL (15.0 mL of a $10.0 \mathrm{ppm}$ solution) and were sealed in a closed system in the absence of light for $5 \mathrm{~h}$.

Evaluation of the adsorption and of the photocatalysis was performed by measurement of the discoloration percentage. UV-vis analysis of the resulting solution was performed after centrifugation and filtering of the suspension. The same equipment described before was used, but in transmittance mode. The discoloration percentage was obtained from the band at $410 \mathrm{~nm}$, which is assigned to the $\mathrm{N}=\mathrm{N}$ bond, i.e., the azo bond. The values were calculated using a calibration curve obtained from the intensity of the absorption band at $410 \mathrm{~nm}$ of solutions with known concentrations of RNL. Discoloration due to photolysis was subtracted from the discoloration percentage.

\section{Results and discussion}

\subsection{Characterization of the photocatalysts}

\subsubsection{X-ray diffraction}

XRD patterns of all of the samples are presented in Fig. 1. The patterns were indexed to a cubic unit cell (ICDD 74-1300) in the case of $\mathrm{BaSnO}_{3}$ and to an orthorhombic one (ICDDD 22-1442) in the case of $\mathrm{SrSnO}_{3}$. No ICDD pattern was found for the solid solution.

The XRD patterns confirmed the formation of the perovskite structure. A solid solution was obtained for all of the intermediate compositions (from $x=0.25$ to $x=0.75$ ), and it was confirmed by the shift of the peaks to smaller angles in the XRD patterns as $\mathrm{Sr}^{2+}$ was substituted by $\mathrm{Ba}^{2+}$. Small peaks were observed at $26.7^{\circ}$ and $33.9^{\circ}$ in the patterns of 
$\mathrm{SrSnO}_{3}$ and $\mathrm{Sr}_{0.75} \mathrm{Ba}_{0.25} \mathrm{SnO}_{3}$; these peaks were assigned to $\mathrm{SnO}_{2}$, which was present as a secondary phase (ICDD 078-1063). Mountstevens et al. [8] and Glerup et al. [21] also synthesized $\mathrm{SrSnO}_{3}$ by solid-state reaction and obtained single-phase materials; however, a higher temperature $\left(1380^{\circ} \mathrm{C}\right)$ was used by Mountstevens et al., whereas Glerup et al. employed two heat treatments at $1200^{\circ} \mathrm{C}$ for $8 \mathrm{~h}$. Stanulis et al. [22] have synthesized $\mathrm{SrSnO}_{3}$ using a new sol-gel method for the formation of crystalline phases at temperatures between 700 and $900{ }^{\circ} \mathrm{C}$; this method resulted in formation of $\mathrm{SnO}_{2}$ at higher temperatures.

The structural parameters determined via Rietveld refinement (Fig. 2) are shown in Table 1, in addition to the $\mathrm{Ba}^{2+} /\left(\mathrm{Sr}^{2+}+\mathrm{Ba}^{2+}\right)$ ratio obtained by EDS. Perovskites with different crystalline structures were obtained as a function of the composition, varying from orthorhombic for $\mathrm{SrSnO}_{3}$ and $\mathrm{Sr}_{0.75} \mathrm{Ba}_{0.25} \mathrm{SnO}_{3}$ (space group $\mathrm{Pbnm}$ ) to cubic for $\mathrm{BaSnO}_{3}$ and $\mathrm{Sr}_{0.25} \mathrm{Ba}_{0.75} \mathrm{SnO}_{3}$ (space group $\mathrm{Pm} 3 \mathrm{~m}$ ) in addition to the tetragonal structure for $\mathrm{Sr}_{0.50} \mathrm{Ba}_{0.50} \mathrm{SnO}_{3}$ (space group $I 4 / \mathrm{mcm}$ ); these results are in agreement with previous results reported in the literature [23-28]. The change of the space group for the different compositions is due to the substitution of $\mathrm{Sr}^{2+}$ for $\mathrm{Ba}^{2+}$ (i.e., the $\mathrm{A}$ cation); $\mathrm{Sr}^{2+}$ ions are smaller than $\mathrm{Ba}^{2+}$ ions, which leads to an $\mathrm{A}-\mathrm{O}$ bond with greater covalent character.

Yuan et al. [15] prepared $\mathrm{Ba}_{1-\mathrm{x}} \mathrm{Sr}_{\mathrm{x}} \mathrm{SnO}_{3}$ perovskites by the polymerized complex method and reported the same space groups observed in the present work for the samples with $x=0,0.25,0.75$ and 1 , whereas the sample with $x=0.50$ exhibited a different space group of Pbnm. Mizoguchi et al. [17] reported a space group of ( $\mathrm{Pnma}$ ) for $\mathrm{SrSnO}_{3}$, which is similar to the space group (Pbnm). This change in space group is related to the bonding among octahedra. According to Zhang et al. [23], when $\mathrm{Sr}^{2+}$ occupies the cubic-octahedral cavity, octahedra tilt, which changes the crystalline structure but maintains the local octahedral configuration among $\mathrm{O}^{2-}$ and $\mathrm{Sn}^{4+}$ ions. 


\subsubsection{Infrared spectroscopy}

The infrared spectra of all of the samples are shown in Fig. 3. Three vibrational modes were expected for the $\mathrm{ABO}_{3}$ perovskites: $v 1$, which is related to the $\mathrm{B}-\mathrm{O}$ stretch; $v 2$, which is assigned to the $\mathrm{B}-\mathrm{O}-\mathrm{B}$ bend; and $v_{3}$, which is related to the $\mathrm{A}-\mathrm{BO}_{3}$ lattice mode [29-31]. Some splitting may occur in the case of distorted perovskites, which leads to additional bands [32]. In the present case, the $v_{1}$ vibration was observed at approximately $669 \mathrm{~cm}^{-1}$, with small shoulders between 574 and $534 \mathrm{~cm}^{-1}$; these shoulders were especially

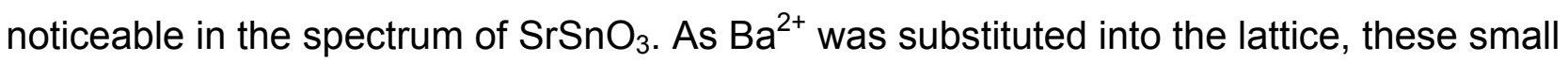
shoulders became less defined, most likely due to a smaller distortion of the octahedra.

In addition to the vibrations assigned to the perovskite, additional bands were also observed at $1772 \mathrm{~cm}^{-1}$ (small), $1463 \mathrm{~cm}^{-1}$ (broad or with a high intensity) and $860 \mathrm{~cm}^{-1}$ (medium size). These bands were more intense in the spectrum of $\mathrm{SrSnO}_{3}$, which is related to the vibrational mode $v\left(A-\mathrm{CO}_{3}^{2-}\right)$ of the carbonates used as precursors; these results indicate that decomposition of the carbonates during the heat treatment was not complete [33]. Differences in the intensity are most likely related to the synthesis temperatures. The presence of $\mathrm{SrCO}_{3}$ may be responsible for the formation of $\mathrm{SnO}_{2}$ (Fig. 1) because stoichiometric amounts of Sr and Sn were used in the synthesis.

\subsubsection{Micro-Raman spectroscopy}

Raman spectra of all of the samples are shown in the Fig. 4. The Raman spectra of perovskites are well described in the literature. For orthorhombic perovskites (Pbnm) such as $\mathrm{SrSnO}_{3}, 24$ active modes may be present; however, not all of them are always observed due to overlapping and due to the low polarizability of certain modes [23].

The spectrum of $\mathrm{SrSnO}_{3}$ shows lattice soft modes below $173 \mathrm{~cm}^{-1}$, scissoring modes of the Sn-O-Sn groups at approximately $223 \mathrm{~cm}^{-1}$ and $\mathrm{O}-\mathrm{Sn}-\mathrm{O}$ bending motions and Sn- 
O-Sn scissoring motions at approximately $252 \mathrm{~cm}^{-1}$. A set of bands at approximately 380 and $450 \mathrm{~cm}^{-1}$ and a band between 640 and $710 \mathrm{~cm}^{-1}$ are also expected; these bands are related to a Sn- $\mathrm{O}_{3}$ torsion mode and to a stretching mode, respectively. Additional bands at 721,745 and $1148 \mathrm{~cm}^{-1}$ can also be observed; these bands are assigned to the presence of defects or disorder in the $\mathrm{SrSnO}_{3}$ perovskite structure. For cubic perovskites such as $\mathrm{BaSnO}_{3}$, no vibration mode should be observed because of its highly symmetric structure (space group $\operatorname{Pm} 3 \bar{m})[23,34-36]$.

In the present work, the bands observed for $\mathrm{SrSnO}_{3}$ were in agreement with the literature, as previously reported, except for a well defined band at $202 \mathrm{~cm}^{-1}$, which was not assigned to this perovskite, to $\mathrm{SrCO}_{3}$ or to $\mathrm{SnO}_{2}$. This band can be assigned to the hydration of the perovskite structure [37]; however, the presence of non-ordered reduced tin oxide (SnO) cannot be excluded [38-40].

The spectra of the other compositions were widely influenced by the cationic substitution into the A sites, as already reported in the literature [36]. For $\mathrm{Sr}_{0.75} \mathrm{Ba}_{0.25} \mathrm{SnO}_{3}$, the intensity of the lattice mode $\left(171 \mathrm{~cm}^{-1}\right)$ exhibited a meaningful decrease, whereas a broad band was observed at $203 \mathrm{~cm}^{-1}$ along with quite small bands at approximately 270 and $305 \mathrm{~cm}^{-1}$. Tenne et al. [41] have observed second-order modes in the spectra of $\mathrm{Sr}_{0.8} \mathrm{Ba}_{0.2} \mathrm{TiO}_{3}$ monocrystals at approximately $220 \mathrm{~cm}^{-1}$, similar to the result observed in the present work for $\mathrm{Sr}_{0.75} \mathrm{Ba}_{0.25} \mathrm{SnO}_{3}$. The inset of Fig. 4 shows that the spectra of $\mathrm{Sr}_{0.50} \mathrm{Ba}_{0.50} \mathrm{SnO}_{3}, \mathrm{Sr}_{0.25} \mathrm{Ba}_{0.75} \mathrm{SnO}_{3}$ and $\mathrm{BaSnO}_{3}$ contain very small bands between 400 and $500 \mathrm{~cm}^{-1}$ despite the cubic symmetry of the latter two phases. The presence of these bands indicates that the $\mathrm{SnO}_{6}$ octahedra became disordered with a change in its symmetry as already observed by other authors [23,42]. In the case of $\mathrm{BaSnO}_{3}$, broad bands at 668 and $739 \mathrm{~cm}^{-1}$ were also observed by Cerdà et al. [43], who attributed these bands to the presence of local defects. 


\subsubsection{UV-visible spectroscopy}

UV-vis spectra and the band gaps of the $\mathrm{Sr}_{1-\mathrm{x}} \mathrm{Ba}_{\mathrm{x}} \mathrm{SnO}_{3}$ samples are presented in Fig. 5. A meaningful decrease in the band gaps was observed as the amount of $\mathrm{Ba}^{2+}$ increased in the solid solution. The values reported in the present work were similar to those reported by Mizoguchi et al. [2] and Lee et al. [44] for $\mathrm{SrSnO}_{3}$ (approximately $4.0 \mathrm{eV}$ ) and $\mathrm{BaSnO}_{3}$ (3.1 eV). Mizoguchi et al. [2] have compared the band gaps of $\mathrm{BaSnO}_{3}$ and $\mathrm{CaSnO}_{3}$ both theoretically and experimentally. They also observed smaller values for $\mathrm{BaSnO}_{3}$ and attributed this behavior to the increased electronegativity of the $\mathrm{Ca}^{2+}$ ion (better energetic overlap) and especially to the octahedral tilting distortion (better spatial overlap). According to Yuan et al. [15], as tilting among $\mathrm{SnO}_{6}$ octahedra increases, the $\mathrm{Sn} 5 \mathrm{~s}$ non-bonding character at the minimum of the conduction band is lost and anti-bonding $\mathrm{Sn} 5 \mathrm{~s}-\mathrm{O} 2 p$ contributions become more important. As a consequence, the minimum energy of the conduction band is pushed up, which results in a corresponding increase in the band gap.

\subsubsection{Scanning electron microscopy}

FE-SEM micrographs of $\mathrm{Sr}_{1-\mathrm{x}} \mathrm{Ba}_{\mathrm{x}} \mathrm{SnO}_{3}$ powders are presented in Fig. 6. A meaningful influence of the composition on the microstructure was observed, with an increase in the average grain size besides an increase in the grain size distribution $\left(\mathrm{SnSrO}_{3}\right.$ $=160 \pm 64 \mathrm{~nm} ; \mathrm{Sr}_{0.75} \mathrm{Ba}_{0.25} \mathrm{SnO}_{3}=205 \pm 44 \mathrm{~nm} ; \mathrm{Sr}_{0.50} \mathrm{Ba}_{0.50} \mathrm{SnO}_{3}=250 \pm 68 \mathrm{~nm} ;$ $\mathrm{Sr}_{0.25} \mathrm{Ba}_{0.75} \mathrm{SnO}_{3}=265 \pm 87 \mathrm{~nm}$ and $\mathrm{BaSnO}_{3}=310 \pm 133 \mathrm{~nm}$ ) as barium is substituted into the perovskite structure. This behavior is related to the different synthesis temperatures necessary to obtain the desired phase.

\subsection{Discoloration of azo-dye solutions}




\subsubsection{Photocatalytic tests}

UV-vis spectra of the RNL solutions after photocatalytic test are presented in Fig. 7. The band at $410 \mathrm{~nm}$ is characteristic of the azo group [45] responsible for the color of the dye [46]. The intensity of this band decreased after photocatalytic treatment in the presence of the perovskite, which indicated that discoloration occurred $[10,44,47]$. The results presented in Fig. 7 indicate that the extent of photodiscoloration increased as the amount of $\mathrm{Ba}^{2+}$ substituted into the perovskite increased. As a result, the percentage of discoloration reached in the presence of $\mathrm{BaSnO}_{3}$ was almost twice that achieved in the presence of $\mathrm{SrSnO}_{3}$

Despite the scarcity of results related to the use of stannates in the photodegradation of textile dyes, some authors have reported the use these materials for the photocatalytic splitting of water. Borse et al. [10,47] and Yuan et al. [15], in different papers, reported a nil photocatalytic activity for $\mathrm{BaSnO}_{3}$ that improved with the addition of $\mathrm{Pb}$ or $\mathrm{Sr}$ into the perovskite lattice. Chen et al. [48] and Zhang et al. [23] have evaluated the use of $\mathrm{SrSnO}_{3}$ with 0.5 wt $\%$ Pt as a co-catalyst. Different methods of synthesis have been used to obtain the perovskite in these papers: hydrothermal synthesis and solid-state reaction. Catalysts obtained via the hydrothermal method exhibited efficiencies almost ten times greater than those of samples prepared by solid-state reaction, which has been attributed to the greater surface area of $\mathrm{SrSnO}_{3}$ prepared via the hydrothermal method. With respect to the photocatalytic degradation of dyes, Junploy et al. [16] achieved $85 \%$ discoloration of methylene blue after 320 min of UV irradiation in the presence of $\mathrm{SrSnO}_{3}$.

The results obtained in the present work differ substantially from those reported in the literature for photocatalytic water splitting when the solid solution $\mathrm{Sr}_{1-x} \mathrm{Ba}_{\mathrm{x}} \mathrm{SnO}_{3}$ was used because, according to our results, $\mathrm{BaSnO}_{3}$ led to highest discoloration percentage. 
Differences in surface area may not be the reason for the differences in the discoloration percentages especially considering that samples with the highest particle size showed the highest discoloration percentage.

The photocatalytic behavior can be understood by considering the possible mechanisms of dye photodegradation, i.e., the direct and indirect mechanisms [49-55]. When a semiconductor with an appropriate band-gap energy is irradiated with ultraviolet radiation, electrons are excited into the conduction band $\left(\bar{\theta}_{\bar{C} B}\right)$ and holes are formed in the valence band $\left(\boldsymbol{h}_{V_{B}}^{*}\right)$. According to the direct mechanism, these photogenerated electrons may interact with the organic molecules of an azo dye adsorbed onto the surface of a catalyst, thereby leading to the formation of $\mathrm{R}^{+}$and then to its degradation. These electrons may also interact with acceptor molecules such as $\mathrm{O}_{2}$ adsorbed onto the surface of a semiconductor or dissolved in water, thereby leading to the formation of a superoxide. According to the indirect mechanism, the photogenerated holes may oxidize species such as $\mathrm{OH}^{-}$or $\mathrm{H}_{2} \mathrm{O}$, thereby forming $\bullet \mathrm{OH}^{-}$free radicals, which are a strong oxidizing agent that can react with most textile dyes $[10,46,56]$.

\subsubsection{Adsorption tests}

The literature data indicates that $\mathrm{BaSnO}_{3}$ has a low efficiency in water splitting. Thus, the indirect mechanism of photocatalytic degradation may not be the most important one with respect to dye discoloration. To understand the results obtained in the photocatalytic tests, we performed adsorption tests; the results are shown in Fig. 8.

The results in Fig. 8 indicate that degree of adsorption onto $\mathrm{BaSnO}_{3}$ is more than three times greater than that onto $\mathrm{SrSnO}_{3}$. This adsorption does not lead to the breaking of the $\mathrm{N}=\mathrm{N}$ bond, and discoloration is simply related to the decrease in the concentration of the RNL adsorbed onto the catalyst after its removal from the solution. A comparison of 
discoloration due to adsorption and discoloration due to photocatalysis reveals that the percentage increased from $14.7 \%$ to $38.0 \%$ for $\mathrm{SrSnO}_{3}$, which represents a $158 \%$ increase, whereas it increased from $47.3 \%$ to $74.0 \%$ in the case of $\mathrm{BaSnO}_{3}$, which represents a $56 \%$ improvement. This result indicates that the direct mechanism is most likely more important for dye discoloration on $\mathrm{BaSnO}_{3}$, whereas the indirect mechanism is most likely more important in the case of $\mathrm{SrSnO}_{3}$.

According to Yuan et al. [15], the greater electronegativity of $\mathrm{Sr}^{2+}$ and the short $\mathrm{Sr}-\mathrm{O}$ distance that results from octahedral tilting distortion relative to the octahedral in $\mathrm{BaSnO}_{3}$ provides favorable opportunities for charge-carrier transport. However, the bottom of the conduction band was gradually pushed up as $x$ was increased from $x=0$ to $x=1.0$ in $\mathrm{Sr}_{1-\mathrm{x}} \mathrm{Ba}_{x} \mathrm{SnO}_{3}$. Higher energy levels result in stronger reducing ability of the photoinduced electrons. As a consequence, the photoinduced electrons of $\mathrm{SrSnO}_{3}$ have enhanced reducing ability and $\mathrm{SrSnO}_{3}$ provides favorable opportunities for charge-carrier transport. As a consequence, the formation of superoxide and hydroxyl radicals is favored, which leads to an indirect mechanism of dye photodegradation. Because some adsorption of RNL onto $\mathrm{SrSnO}_{3}$ was observed (Fig. 8), the direct mechanism may also play an important role in this photocatalytic reaction, but it does not appear to be the most important mechanism.

$\mathrm{BaSnO}_{3}$ exhibits small reducing ability, as also reported by Borse et al. $[10,47]$ in two different papers, which causes it to exhibit low efficiency in the photocatalytic splitting of water. As a consequence, the formation of hydroxyl radicals is not favored, which decreases the efficiency of the indirect mechanism. In the case of this perovskite, the direct mechanism appears to prevail as a consequence of its higher adsorption capability. This behavior may be related to the high ionic character of the $\mathrm{Ba}^{2+}-\mathrm{O}^{2-}$ bond, which may lead to an active site for interaction with the $\mathrm{SO}_{3}{ }^{-}$groups present in the $\mathrm{RNL}$ structure that were originally bonded to $\mathrm{Na}^{+}$. 


\section{Conclusion}

The perovskite structure was highly influenced by the modifier cation $\mathrm{Sr}^{2+}$ or $\mathrm{Ba}^{2+}$. The space group and the tilting among octahedra changed when barium was substituted into the lattice, which was accompanied by a decrease in the band gap. As a consequence, the efficiency of the different perovskites in the photodegradation of the azo dye differed among the different materials, with an almost linear increase in photodegradation as the barium was substituted for strontium; the photodegradation varied from $38.0 \%$ for $\mathrm{SrSnO}_{3}$ to $74.0 \%$ for $\mathrm{BaSnO}_{3}$. A comparison of the discoloration during the photocatalytic test with the discoloration due to adsorption revealed that a higher efficiency was attained when UV irradiation was used, especially for $\mathrm{SrSnO}_{3}$, with an increase of $158 \%$, whereas a $56 \%$ improvement was observed in the case of $\mathrm{BaSnO}_{3}$. These results may indicate that a direct mechanism of photodegradation is favored for $\mathrm{BaSnO}_{3}$, where excited electrons interact with azo-dye molecules adsorbed onto the perovskite surface. In the case of $\mathrm{SrSnO}_{3}$, the indirect mechanism appears to be the most prevalent mechanism, where hydroxyl radicals are formed by water splitting and oxidize the azo-dye molecules.

\section{Acknowledgements}

The authors acknowledge CAPES-COFECUB (Project 644/09), INCT/CNPq/MCT, RECAM/CNPq/MCT and PROINFRA/FINEP/MCT for financial support, J. Le Lannic for SEM images at CMEBA of University of Rennes and Marwène Oumezzine for his help in the Rietveld refinements. 


\section{References}

[1]. Alves, M. C. F.; Souza, S. C.; Lima, H. H. S.; Nascimento, M. R.; Silva, M. R. S.;

Espinosa, J. W. M.; Lima, S. J. G., Longo, E.; Pizani, P. S.; Soledade, L. E. B.; Souza, A. G.; Santos, I. M. G.; J. Alloys Compd.; 476, (2009), 507-512;

[2]. Mizoguchi, H.; Hang W. Eng. and Patrick M. Woodward; Inorg. Chem.; 43, (2004), 16671780;

[3]. Smith, M. G.; Goodenough, J. B.; Manthiram, A.; J. Solid State Chem.; 98, (1992), 181186;

[4]. Stokes, H. T.; Kisi, E. H.; Hatch, D. M. and Howard; Acta Crystallogr. B; 58, (2002); 934938;

[5]. Bouhemadou, A.; Haddadi, K.; Solid State Sci.; 12, (2010), 630-636;

[6]. Kato, H.; Kado, A.; J. Phys. Chem. B; 106, (2002), 5029-5034;

[7]. Smith, A. J.; Welch, J. E.; Acta Cristalogr.; 13, (1960), 653-656;

[8]. Mountstevens, E. H.; Attfield, J. P.; Redfern, S. A. T.; J. Phys-Condens. Mat.; 15, (2003), 8315-8326;

[9]. Mountstevens, E. H.; Redfern, S. A. T.; Phys. Rev. B; 71, (2005), 220102R;

[10]. Borse, P. H.; Joshi, U. A.; Ji, S. M.; Jang, J. S.; Lee, J. S.; Appl. Phys. Lett.; 90, (2007), 034103;

[11]. Bucur, R. L.; Bucur, A. L.; Novaconi, F.; Nicoara, I.; J. Alloys Compd.; 542, (2012), 142-146;

[12]. Di Paola, A.; García-López, E.; Marcì, G.; Palmisano, L.; J. Hazard. Mater.; 211-212, (2012), 3-29;

[13]. Kocemba, I.; Wróbel-Jedrzejewska, M.; Szychowska, A.; Rynkowski, J.; Glówka, M.; Sensor and Actuat. B; 121, (2007), 401-405; 
[14]. Shi, J.; Guo, L.; Prog. Nat. Sci.: Mat. Int.; 22, (2012), 592-615;

[15]. Yuan, Y.; Lv, J.; Jiang, X.; Appl. Phys. Lett.; 91, (2007), 094107.

[16]. Junploy, P.; Thongtem, S.; Thongtem, T.; Superlatices and Microst.; 57, (2013), 1-10;

[17]. Mizoguchi, H.; Woodward, P. M.; Park, C. H.; Keszler, A. D.; Strong Near-infrared Luminescence in $\mathrm{BaSnO}_{3}$; J. Am. Chem. Soc.; 126, (2004a), 9796.

[18]. Roisnel, T.; Carvajal, J. R.; Program: Fullprof, LLB-LCSIM, France, 2000;

[19]. Wood, D. L.; Tauc, J.; Phys. Rev. B; 5, (1972), 3144-3151;

[20]. Bouzaza, A.; Laplanche, A.; J. Photoch. Photobio. A; 150, (2002), 207-212;

[21]. Glerup, M.; Knight, K. S.; Poulsen, F. W.; Mat. Res. Bull.; 40, (2005), 507-520;

[22]. Stanulis, A; Selskis, A.; Ramanauskas, R.; Geganskiene, A.; Kareiva, A.; Mat. Chem. Phys.; 130, (2011), 1246-1250;

[23]. Zhang, W.; Tang, J.; Ye, J.; J. Mat. Res.; 22, (2007), 1859-1871;

[24]. Glazer, A. M.; Acta Crystallogr. B; B28, (1972), 3384;

[25]. Howard, C. J.; Stokes, H.; Acta Crystallogr. B; B54, (1998), 782-789;

[26]. Lafuso, M. W.; Woodward, P. M.; Acta Crystallogr. B; B57, (2001), 725-738;

[27]. Woodward, D. I.; Reaney, I. M.; Acta Crystallogr. B; B61, (2005), 387-399;

[28]. Moreira, E.; Henriques, J. M.; Azevedo, D. L.; Caetano, E. W. S.; Freire, V. N.;

Albuquerque, E. L.; J. Solid State Chem.; 187, (2012), 186-194;

[29]. Ramdas, B.; Vijayaraghavan, R.; Bull. Mat. Sci.; 33, (2010), 75-78;

[30]. Last, J. T.; Phys. Rev.; 105, (1957), 1740-1750;

[31]. Perry, C. H.; Khanna, B. N.; Phys. Rev.; 135, (1964), A408-A412;

[32]. Karlsson, M.; Ahmed, I.; Matic, A.; Eriksson, S. G.; Solid State Ionics; 181, (2010), 126-129;

[33]. Nyquist, R. and Kagel, R.; Infrared Spectra Inorganics Compounds; Academic Press, Inc. (London), 1991; 
[34]. Tarrida, M.; Larguem, H.; Madon, M.; Phys. Chem. Miner.; 36, (2009), 403-413;

[35]. Moreira, E.; Henriques, J. M.; Azevedo, D. L.; Caetano, E. W. S.; Freire, V. N.; Albuquerque, E. L.; J. Solid State Chem.; 184, (2011), 921-928;

[36]. Zheng, H.; Csete de Gyorgyfalva, G. D. C.; Quimby, R.; Bagshaw, H.; Ubic, R.; Reaney, I. R.; Yarwood, J.; J. Eur. Ceram. Soc.; 23, (2003), 2653-2659;

[37]. Colomban, Ph.; Tran, C.; Zaafrani, O.; Slodczyk, A.; J. Raman Spectrosc.; 44, (2013), 312-320;

[38]. Abello, L.; Bochu, B.; Gaskov, A.; Koudryavtseva, S.; Lucazeau, G.; Roumyantseva, M.; J. Solid State Chem.; 135, (1998), 78-85;

[39]. Lin, Chung-Cherng; Liu, Lin-Gun; J. Phys. Chem. Solids; 58, (1997), 977-987;

[40]. Zhurbina, I. A.; Tsetlin, O. I.; Timoshenko, V. Yu; Semiconductors+; 45, (2011), 236240;

[41]. Tenne, D. A.; Soukiassian, A.; Zhu, M. H.; Clark, A. M.; Phys. Rev. B; 67, (2003), 012302;

[42]. Siny, I. G.; Katiyar, R. S.; Bhalla, A. S.; J. Raman Spectrosc.; 29, (1998), 385-390;

[43]. Cerdà, J.; Arbiol, J.; Diaz, R.; Dezanneua, G.; Morante, J. R.; Mat. Lett.; 56, (2002), $131-136$.

[44]. Lee, C. W.; Kim, D. W.; Cho, I. S.; Park, S.; Shin, S. S.; Seo, S. W.; Hong, K. S.; Int. J. Hydrogen Energ.; 37, (2012), 10557-10563;

[45]. Stylid, M.; Kondarides, D. I.; Verykios, X. E.; Appl. Catal. B- Environ.; 47, (2004), 189201;

[46]. Cervantes, T. N. M.; Zaia, D. A. M.; Santana, H.; Quím. Nova; 32, (2009), 2423-2428; Brazil;

[47]. Borse, P. H.; Lee, J. S.; J. Appl. Phys.; 100, (2006), 124915;

[48]. Chen, Di; Ye, J.; Chem. Mater.; 19, (2007), 4585-4591; 
[49]. Galindo, C.; Jacques, P.; Kalt, A.; J. Photoch. Photobio. A; 130, (2000), 35-47;

[50]. Houas, A.; Lachheb, H.; Ksibi, M.; Elaloui, E.; Guillard, C.; Herrmann, Jean-Marie; Appl. Catal. B-Environ.; 31, (2001), 145-157;

[51]. Liu, Chin-Chuan; Hsieh, Yung-Hsu; Lai, Pao-Fan; Li, Chia-Hsin, Kao, Chao-Lang;

Dyes Pigments; 68, (2006), 191-195;

[52]. Mozia, S.; Tomaszewska, M.; Morawski, W.; Dyes Pigments; 75, (2007), 60-66;

[53]. Rauf, M. A.; Asharf, S. S.; Chem. Eng. J.; 151, (2009), 10-18;

[54]. Tanaka, K.; Padermpole, K.; Hisanaga, T.; Water Res.; 34, (2000), 327-333;

[55]. Zhan, H.; Tian, H.; Dyes Pigments; 37, (1998), 231-239;

[56]. Konstantinou, I. K.; Albanis, T. A.; Appl. Catal. B-Environ.; 49, (2004), 1-14 


\section{Table Caption}

Table 1. Refined structural parameters of $\mathrm{Sr}_{1-\mathrm{x}} \mathrm{Ba}_{\mathrm{x}} \mathrm{SnO}_{3}(0 \leq \mathrm{x} \leq 1)$.

\begin{tabular}{|c|c|c|c|c|c|}
\hline \multirow[t]{2}{*}{ Compound } & \multirow[t]{2}{*}{$\begin{array}{c}\text { EDS } \\
\mathbf{B a} /(\mathbf{S r}+\mathbf{B a})\end{array}$} & \multirow[t]{2}{*}{$\begin{array}{l}\text { Crystal } \\
\text { structure }\end{array}$} & Space group & $\begin{array}{c}\text { Lattice parameter } \\
(\AA)\end{array}$ & \multirow[t]{2}{*}{$\mathrm{Chi}^{2}$} \\
\hline & & & & $a=5.711$ & \\
\hline \multirow[t]{3}{*}{$\mathrm{SrSnO}_{3}$} & $0 \%$ & Orthorhombic & Pbnm & $b=5.703$ & 2.81 \\
\hline & & & & $c=8.065$ & \\
\hline & & & & $a=5.749$ & \\
\hline \multirow{2}{*}{\multicolumn{2}{|c|}{$\mathrm{Sr}_{0.75} \mathrm{Ba}_{0.25} \mathrm{SnO}_{3} 25.5 \%$}} & Orthorhombic & Pbnm & $b=5.733$ & 2.49 \\
\hline & & & & $c=8.099$ & \\
\hline \multirow{2}{*}{\multicolumn{2}{|c|}{$\mathrm{Sr}_{0.50} \mathrm{Ba}_{0.50} \mathrm{SnO}_{3} 50.7 \%$}} & Tetragonal & $\mathrm{I} / \mathrm{mcm}$ & $a=5.761$ & 2.64 \\
\hline & & tellagollal & 14/IIC & $c=8.175$ & 2.64 \\
\hline \multicolumn{2}{|c|}{$\mathrm{Sr}_{0.25} \mathrm{Ba}_{0.75} \mathrm{SnO}_{3} 75.3 \%$} & Cubic & $\begin{array}{l}P m \sqrt{3} n \\
\text { Pm3 m }\end{array}$ & $a=4.098$ & 2.65 \\
\hline $\mathrm{BaSnO}_{3}$ & $100 \%$ & Cubic & $\begin{array}{l}P_{n 3}{ }^{-} \\
\mathrm{Pm}^{-} \mathrm{m}\end{array}$ & $a=4.115$ & 2.36 \\
\hline
\end{tabular}




\section{Figure caption}

Fig. 1. XRD patterns of the $\mathrm{Sr}_{1-x} \mathrm{Ba}_{x} \mathrm{SnO}_{3}(0 \leq x \leq 1)$ compounds.

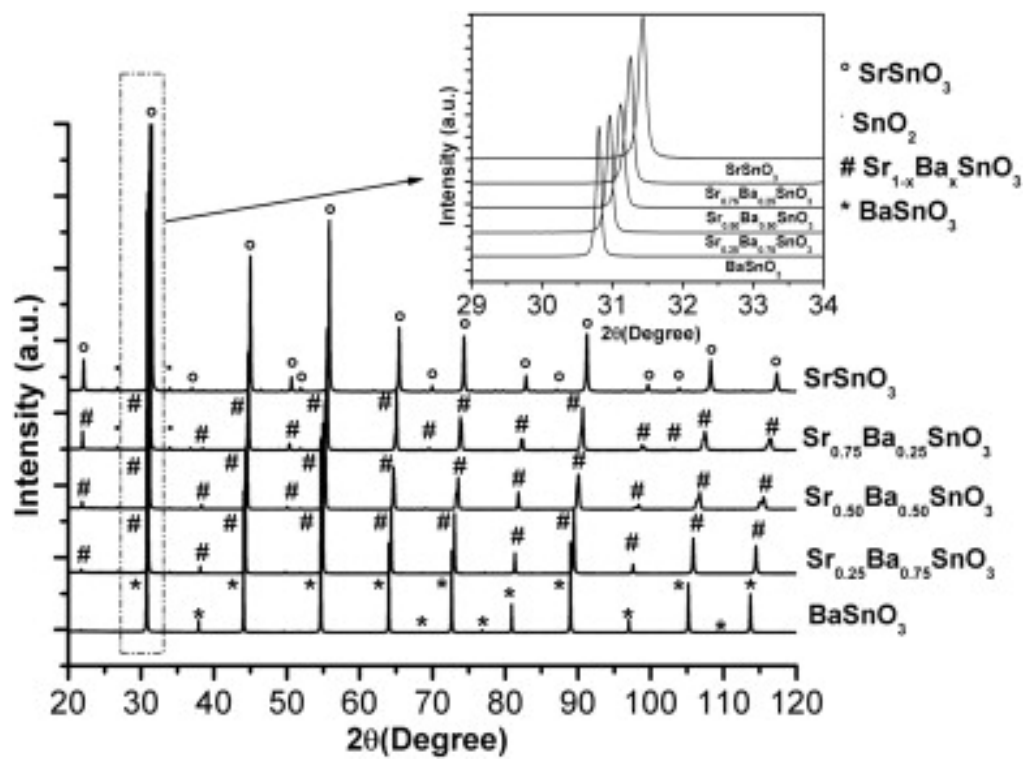

Fig. 2 XRD patterns illustrating the fits obtained by Rietveld calculations. (a) $\mathrm{SrSnO}_{3}$; (b) $\mathrm{BaSnO}_{3}$ 

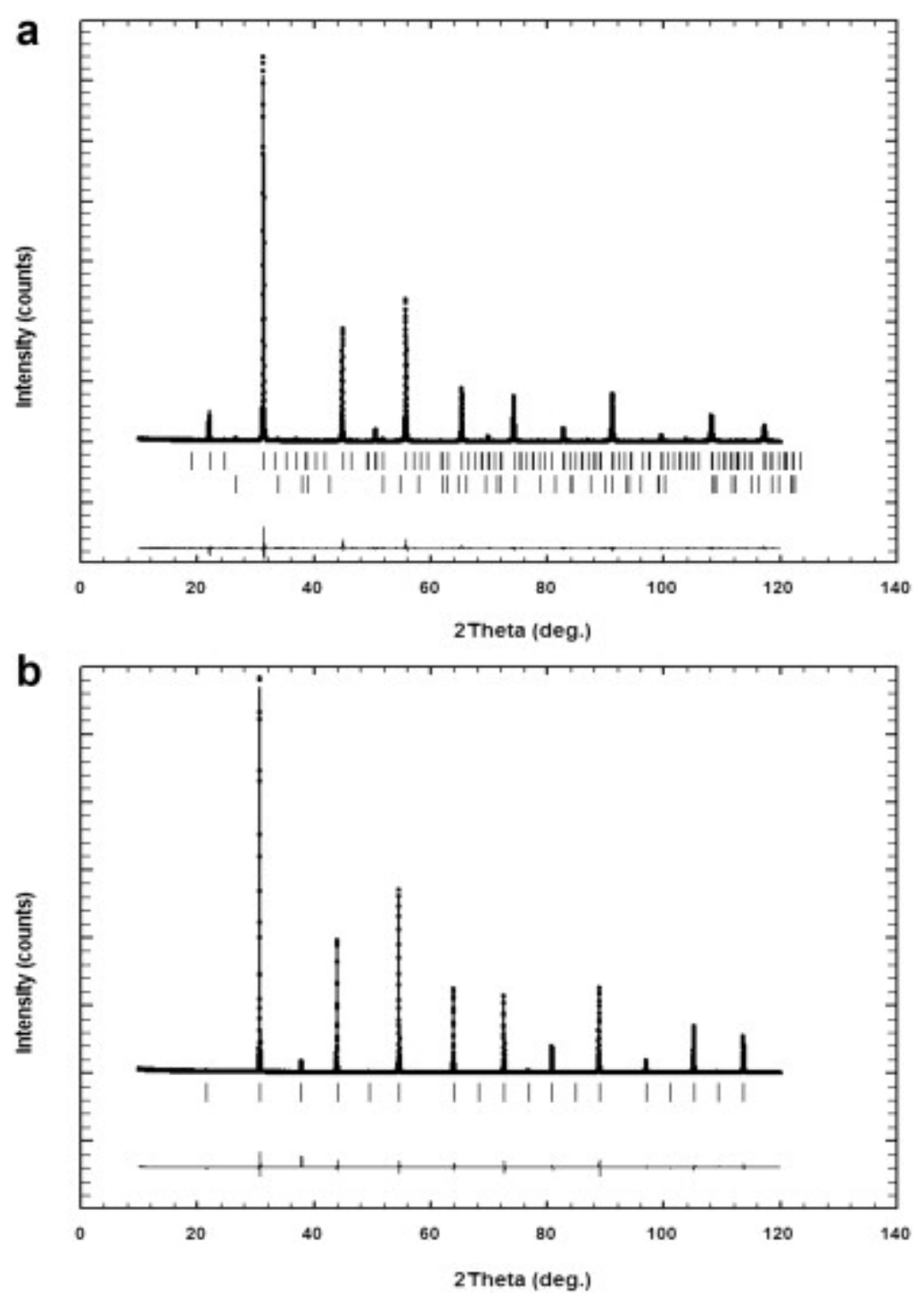

Fig. 3. FT-IR spectra of the $\mathrm{Sr}_{1-\mathrm{x}} \mathrm{Ba}_{x} \mathrm{SnO}_{3}(0 \leq x \leq 1)$ powders.

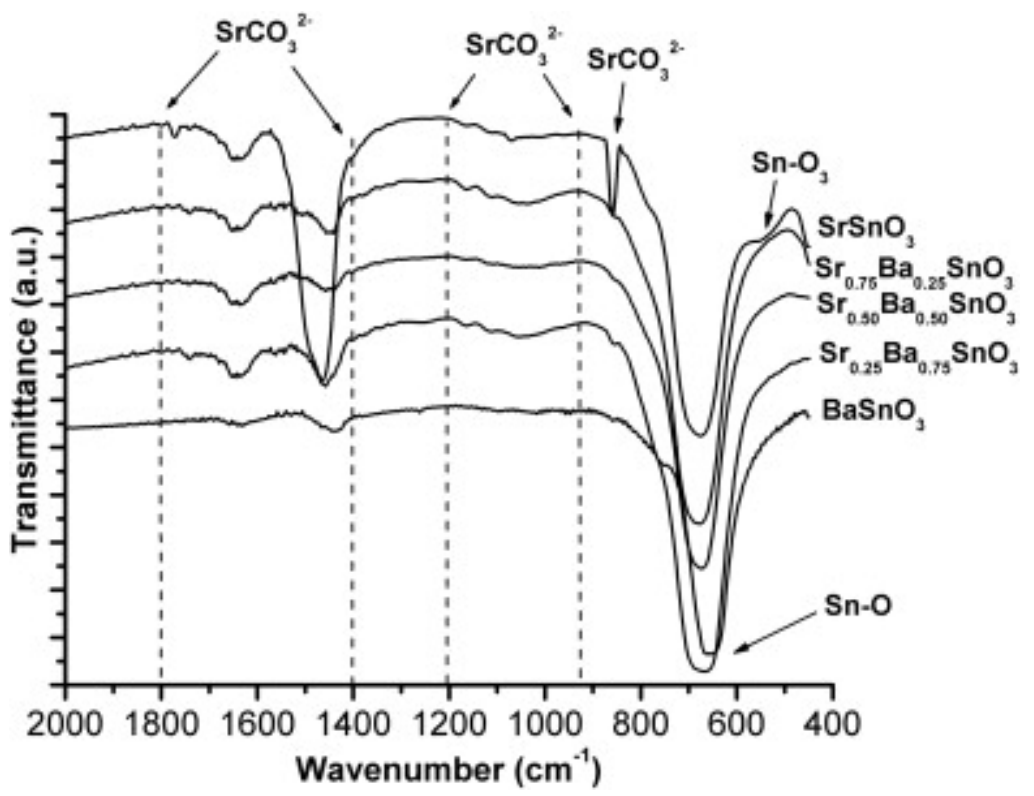


Fig. 4. Raman spectra of the powders: (a) $\mathrm{SrSnO}_{3}$, (b) $\mathrm{Sr}_{0,75} \mathrm{Ba}_{0,25} \mathrm{SnO}_{3}$, (c) $\mathrm{Sr}_{0,50} \mathrm{Ba}_{0,50} \mathrm{SnO}_{3},(\mathrm{~d}) \mathrm{Sr}_{0,25} \mathrm{Ba}_{0,75} \mathrm{SnO}_{3}$, and (e) $\mathrm{BaSnO}_{3}$.

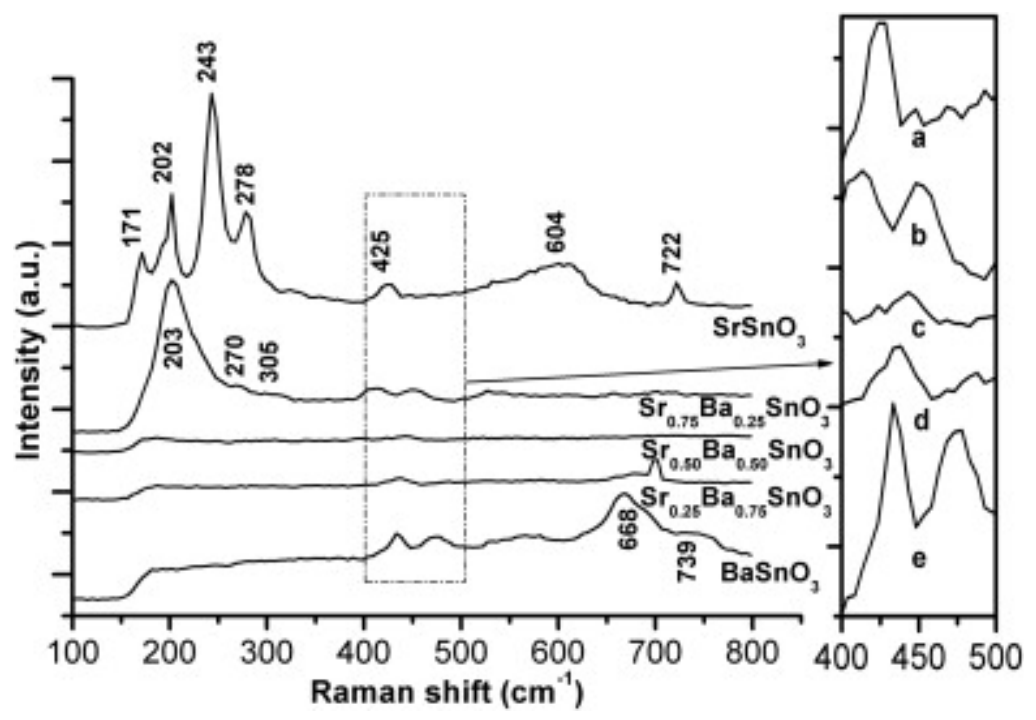

Fig. 5. UV-visible absorption spectra of $\mathrm{Sr}_{1-\mathrm{x}} \mathrm{Ba}_{\mathrm{x}} \mathrm{SnO}_{3}$. The inset shows the estimated band gap values as a function of $\mathrm{x}$.

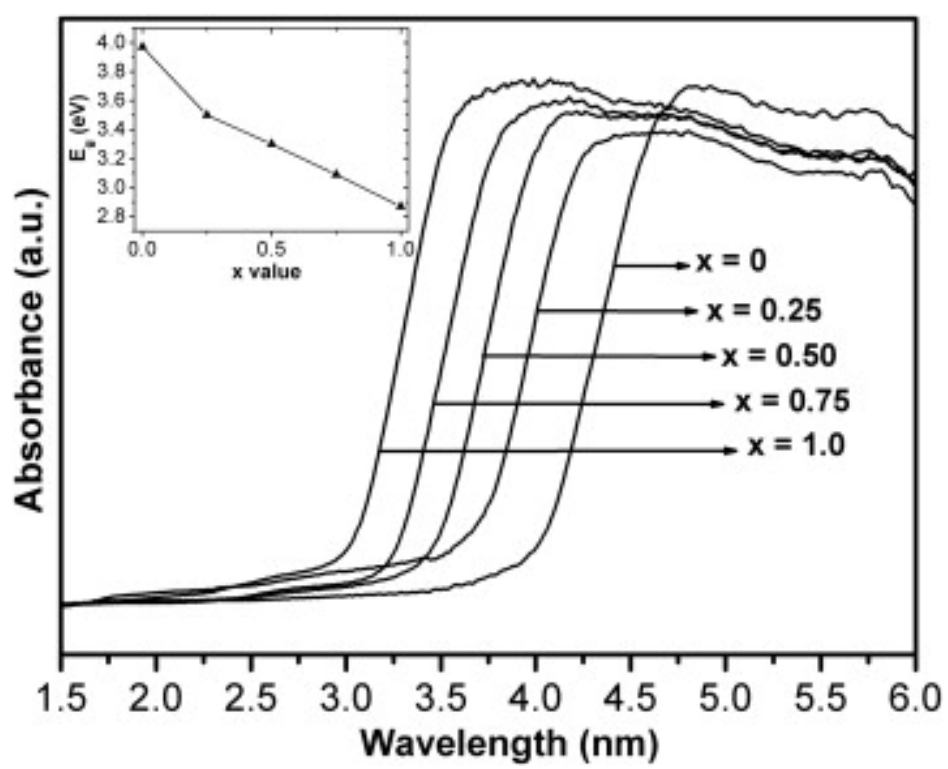

Fig. 6. FE-SEM images of $\mathrm{Sr}_{1-x} \mathrm{Ba}_{x} \mathrm{SnO}_{3 .}$ (a) $\mathrm{SrSnO}_{3}$, (b) $\mathrm{Sr}_{0.75} \mathrm{Ba}_{0.25} \mathrm{SnO}_{3}$, (c) $\mathrm{Sr}_{0.50} \mathrm{Ba}_{0.50} \mathrm{SnO}_{3}$, (d) $\mathrm{Sr}_{0.25} \mathrm{Ba}_{0.75} \mathrm{SnO}_{3}$ and (e) $\mathrm{BaSnO}_{3}$ powders. 

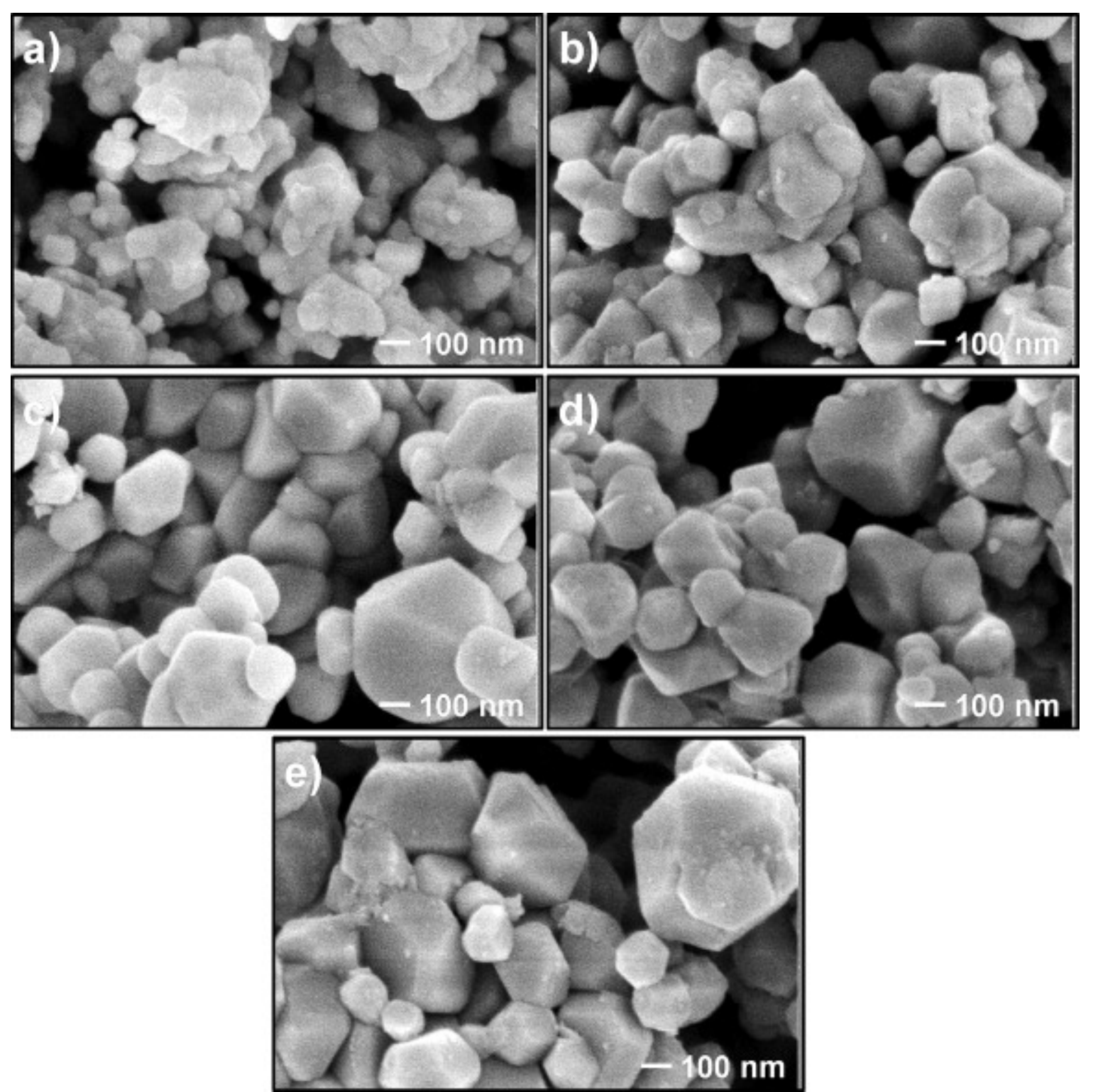
Fig. 7. UV-visible absorption spectra of the textile dye after photocatalysis in the presence of $\mathrm{Sr}_{1-\mathrm{x}} \mathrm{Ba}_{\mathrm{x}} \mathrm{SnO}_{3}$ perovskites powders of various compositions.

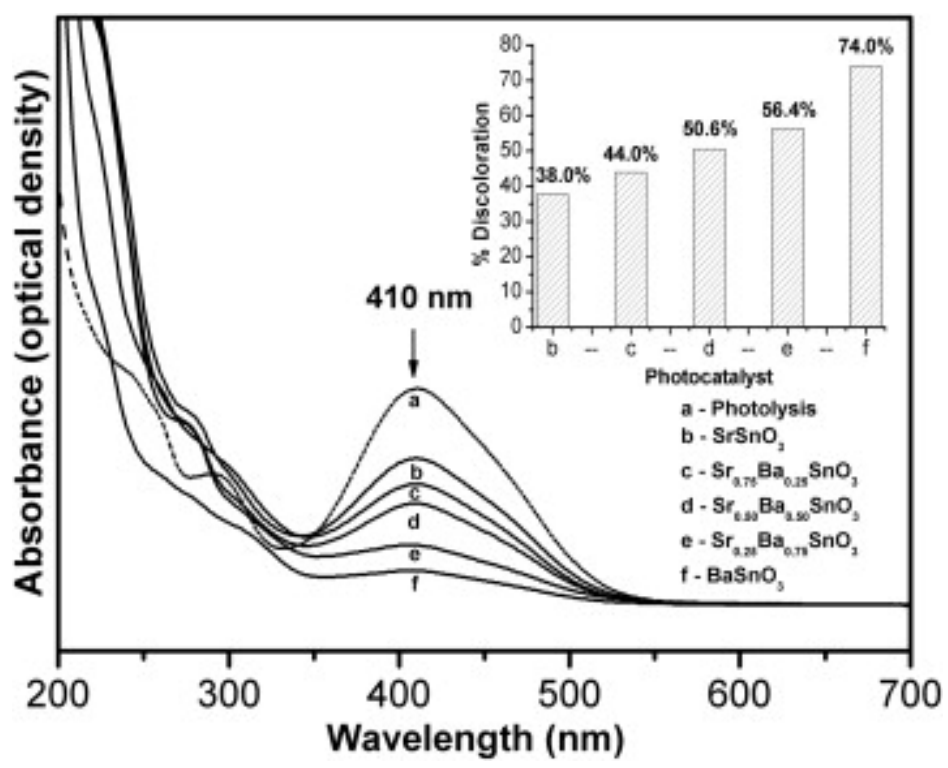

Fig. 8. UV-visible absorption spectra of the textile dye after adsorption in the presence of the $\mathrm{Sr}_{1-\mathrm{x}} \mathrm{Ba}_{\mathrm{x}} \mathrm{SnO}_{3}$ perovskites powders of various compositions.

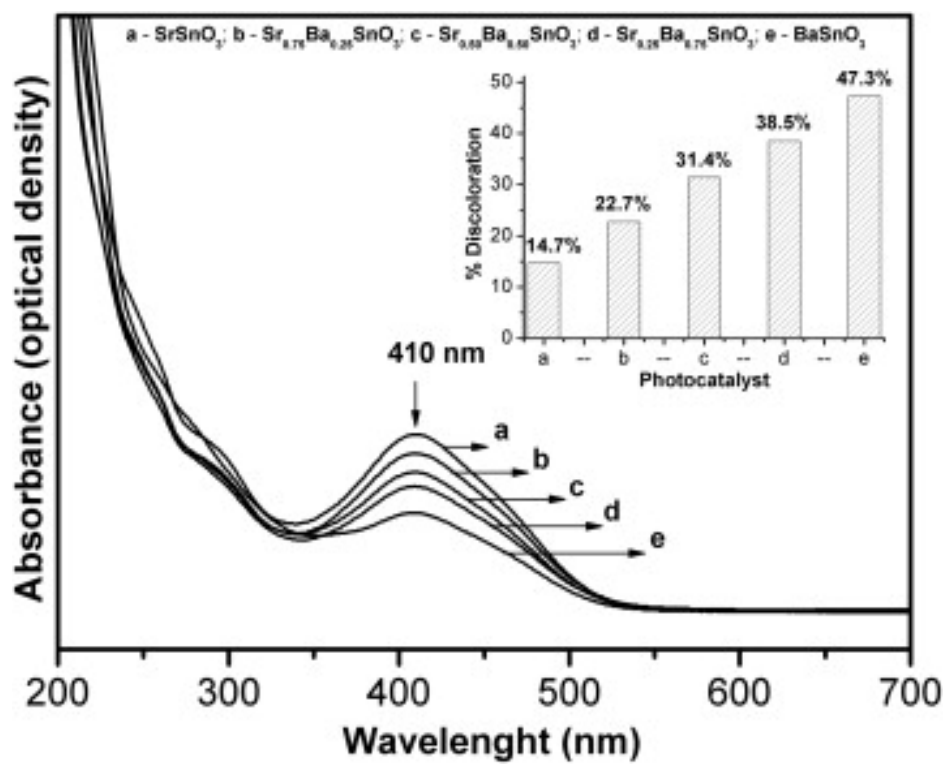

